\title{
Involvement of human chorionic gonadotropin in regulating vasculogenic mimicry and hypoxia-inducible factor-1a expression in ovarian cancer cells
}

\author{
Min $\mathrm{Su}^{1 \dagger}$, Xiangxiang $\mathrm{Xu}^{1,2+}$, Weiwei Wei ${ }^{1,3}$, Sainan Gao ${ }^{1}$, Xiaoying Wang ${ }^{4}$, Caoyi Chen ${ }^{5}$ and Yuquan Zhang ${ }^{1 *}$
}

\begin{abstract}
Background: Human chorionic gonadotropin (hCG) can play a crucial role in angiogenesis. In the present study, we focused on hCG to gain insight into its potential effects on vasculogenic mimicry (VM) in ovarian cancer cells.

Methods: Ovarian cancer OVCAR-3 cells were incubated with different concentrations of recombinant hCG in 3-dimensional cultures. VM was identified by morphological observations and vascular endothelial cell marker detection in OVCAR-3 cells. Expression of hCG, hypoxia-inducible factor-1a (HIF-1a), and the endothelial cell markers CD31, VEGF, and factor VIII were detected by reverse transcription polymerase chain reaction and western blotting. The effect of hCG on endothelial cell-marker expression in ovarian cancer cells was further explored using small interfering RNA (siRNA) and plasmid-based approaches.
\end{abstract}

Results: Incubation of OVCAR-3 cells with recombinant hCG induced vessel-like network formation, which was accompanied by significant elevation of vascular marker expression. Attenuation of hCG expression by siRNA in OVCAR-3 cells suppressed the expression of endothelial cell markers and HIF-1a by tumour cells. Overexpression of hCG in OVCAR-3 cells resulted in increased expression of endothelial cell markers and HIF-1a.

Conclusions: HCG was crucial for changing the phenotype of OVCAR-3 cells to endothelial-like cells. The effect of hCG induction on VM in ovarian cancer cells is potentially associated with HIF-1a.

Keywords: Ovarian cancer, Human chorionic gonadotropin, Vasculogenic mimicry, Hypoxia inducible factor-1a

\section{Background}

The concept of vasculogenic mimicry (VM) was introduced in 1999 and was described as the unique ability of highly aggressive melanoma cells to obtain endothelial-like characteristics and form de novo vascular-like networks. The aggressive tumor cells have the potential to express vascular marker in this novel microcirculation [1]. Tumour cells have direct access to the bloodstream through the tumour cell-lined vessels and tend to

\footnotetext{
*Correspondence: zhangyuquan2011@126.com

${ }^{\dagger} \mathrm{Min}$ Su and Xiangxiang Xu contributed equally to the article

${ }^{1}$ Department of Obstetrics and Gynecology, The Affiliated Hospital

of Nantong University, No 20, Xisi Rd, Nantong 226001,

People's Republic of China

Full list of author information is available at the end of the article
}

spread aggressively due to VM formation [2]. The presence of VM correlates with an increased risk for metastasis and, therefore, poor clinical outcomes [3]. VM has been reported in ovarian cancer, breast cancer, prostate cancer, myeloma, hepatocellular carcinoma, Ewing's sarcoma, and renal clear cell carcinoma [3-9]. The underlying pathogenic mechanisms of VM are unclear, but the influence of the tumour microenvironment is potentially associated with VM formation. Hypoxia was reported to promote VM formation in 3-dimensional (3D) cultures through the hypoxia inducible factor- $1 \alpha$ (HIF- $1 \alpha)$ pathway $[10,11]$.

Choriocarcinoma, which is noted to have high-level human chorionic gonadotropin (hCG) production, is also characterized by the presence of a multitude of 
haemorrhagic channels, similar to VM. Recently, we reported that ovarian cancer cells can express endothelium-associated genes to form vasculogenic-like networks in 3D gels in a microenvironment containing added hCG [12, 13]. HCG belongs to a family of glycoprotein hormones characterized by a heterodimeric structure with an $\alpha$-subunit non-covalently bound to the $\beta$-subunit, the latter being hormone specific [14]. Although $\beta$-hCG is normally expressed at detectable levels during pregnancy, it is also ectopically synthesized in trophoblastic and non-trophoblastic carcinomas of the colon, prostate, bladder, breast, lung, and ovaries [15, 16]. $\beta$-hCG has recently been proposed as a biomarker of poor prognosis in cancer [17-19]. It has been suggested that placental hCG and vascular endothelial growth factor (VEGF) interact during formation of the placental vasculature [20]. Ectopically produced hCG has recently been found to exhibit angiogenic growth factor properties that are central to cancer progression [16]. $\beta$-HCG expression in cervical cancer is associated with the extent of tumour vascularisation [21]. Serum hCG levels have recently been linked to neo-vascularisation of non-seminomatous testicular germ cell tumours [22]. However, little has been reported regarding the effects of hCG on VM.

We hypothesised that hCG may play a crucial role in the development of VM in ovarian cancer. In this study, we explored the possible effects of hCG on VM in the hCG receptor-positive ovarian cancer cell line OVCAR-3 in a 3D angiogenesis system. OVCAR-3 cells were incubated with different concentrations of hCG to evaluate the influence of hCG on VM formation. HCG receptornegative ovarian cancer SKOV3 cells were used as a control. We identified VM by morphological observations and detected vascular marker expression. A small interfering RNA (siRNA) against hCG mRNA and a phCMV1derived hCG expression vector were used to gain insight into the potential effects of hCG on transendothelial differentiation and HIF- $1 \alpha$ expression in OVCAR-3 cells.

\section{Results \\ Vascular cell marker expression and morphological flexibility induced by hCG in OVCAR-3 cells}

OVCAR-3 cells were incubated in 3D gels with increasing concentrations of hCG $(50,500$, or $5000 \mathrm{mU} / \mathrm{ml})$ for 7 days. The expression of vascular cell markers in OVCAR-3 cells was analysed by reverse transcriptionpolymerase chain reaction (RT-PCR) and western blotting. As shown in Fig. 1a, the expression levels of CD31, VEGF, factor VIII mRNA and HIF- $1 \alpha$ increased significantly in response to hCG treatment, in a dose-dependent manner, as did their respective protein-expression levels (Fig. 1b). The highest dose of hCG $(5000 \mathrm{mU} / \mathrm{ml})$ showed the most significant effect. We also found that the relative expression of hCG in OVCAR-3 cells significantly increased in response to hCG treatment in a dose-dependent manner, compared with that observed in unstimulated cells (Fig. 1a-d). However, hCG treatment did not significantly increase expression of the vascular cell marker in SKOV-3 cells.

OVCAR-3 cells displayed considerable plasticity in cell shape when embedded in the 3D matrix under hCG treatment when observed by light and scanning-electron microscopy. Tubular network and channel formation with OVCAR-3 cells were observed in the 3D gel exposed to $5000 \mathrm{mU} / \mathrm{ml} \mathrm{hCG}$ (Fig. 1e). The effects in the 3D gel on exposure to 50 or $500 \mathrm{mU} / \mathrm{ml} \mathrm{hCG}$ with respect to morphological changes were not obvious, compared with the appearance of untreated cells. SKOV-3 cells failed to form tubular networks or channels in the 3D gel, even when exposed to $5000 \mathrm{mU} / \mathrm{ml} \mathrm{hCG}$.

\section{Inhibition of vascular marker and HIF-1a expression in OVCAR- 3 cells by $\beta$-hCG siRNA}

The specificity of the effect of hCG was further assessed by down-regulating $\beta$-hCG expression with siRNA. $\beta$-hCG siRNA specifically suppressed hCG expression. HCG mRNA expression decreased by $71.87 \%$ and hCG protein expression decreased by $85.39 \%$. Our data showed that expression of vascular cell markers in OVCAR-3 cells was inhibited effectively by $\beta$-hCG siRNA. For example, expression of CD31, VEGF, factor VIII mRNA decreased by $57.36,77.05$, and $86.2 \%$, respectively, in OVCAR-3 cells transfected with $\beta$-hCG siRNA, compared with the negative control group. $\beta$-hCG siRNA also reduced CD31, VEGF, Factor VIII protein expression by $82.68,71.05$, and $69.05 \%$, respectively. HIF- $1 \alpha$ mRNA and protein expression was also decreased by 69.53 and $70.61 \%$, respectively (Fig. 2; p $<0.01$ ).

\section{Expression of vascular markers and HIF-1a in OVCAR-3 cells with up-regulated $\beta$-hCG expression}

To further investigate the effect of hCG on the expression of vascular markers in ovarian cancer cells, OVCAR-3 cells were transfected with the phCMV1 vector expressing $\beta$-hCG. HCG mRNA and protein expression in transfected OVCAR-3 cells was verified by RT-PCR and western blot analysis. Compared with parental and vector control cells, a higher level of hCG expression was detected in transfectants overexpressing hCG. HCG expression increased by 6.5 -fold at the mRNA level and 2.7-fold at the protein level. The angiogenic efficacy of hCG was evaluated by analysing the expression of vascular markers in OVCAR-3 cells overexpressing hCG. OVCAR-3 cells transfected with the phCMV1-hCG $\beta$ vector showed a significant increase in the expression 
a

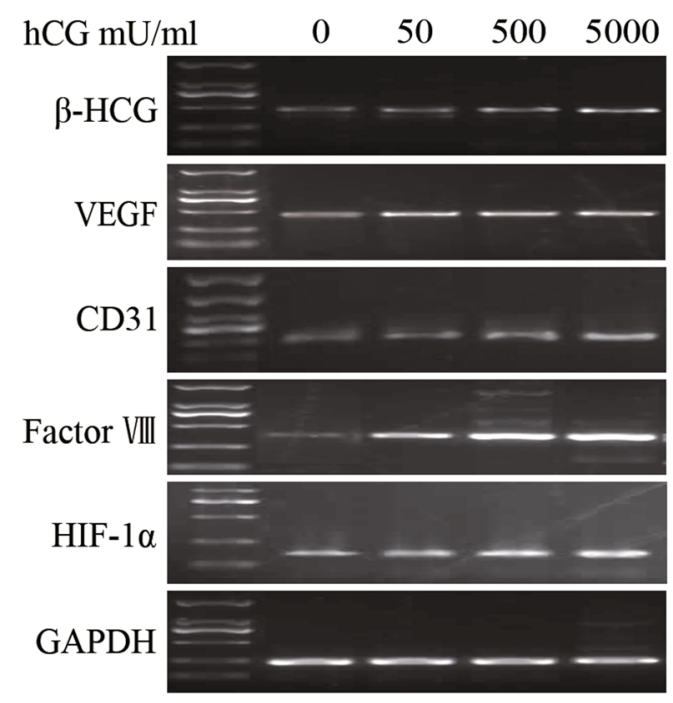

b

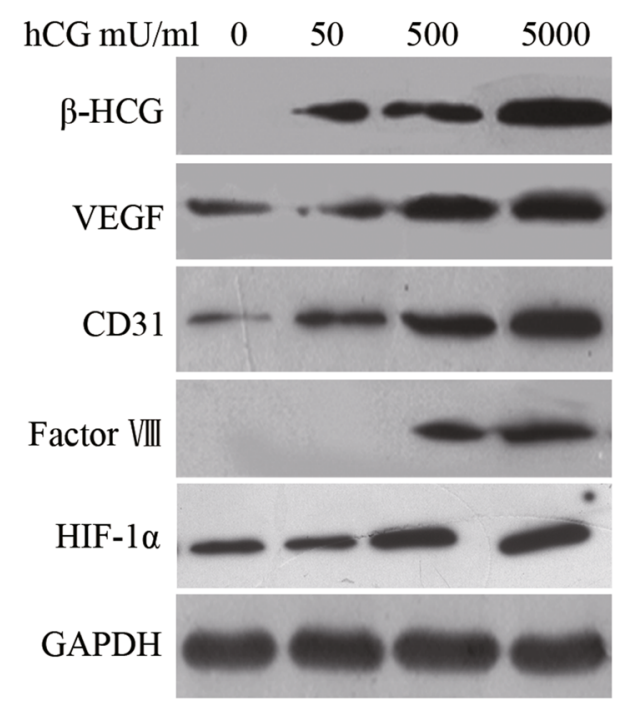

c

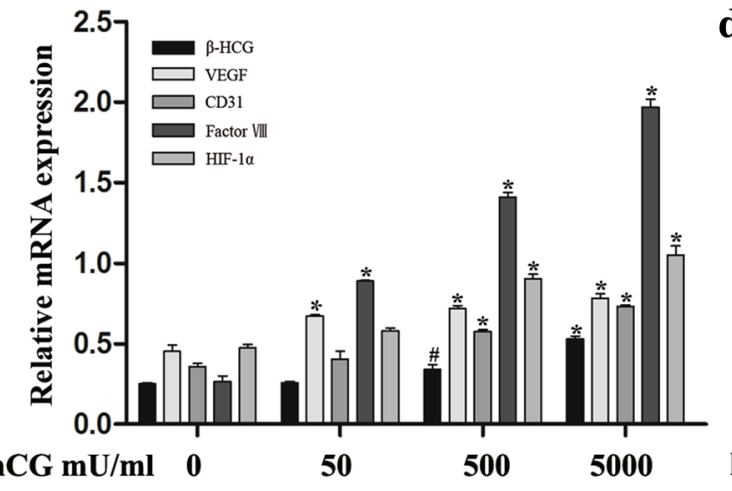

d

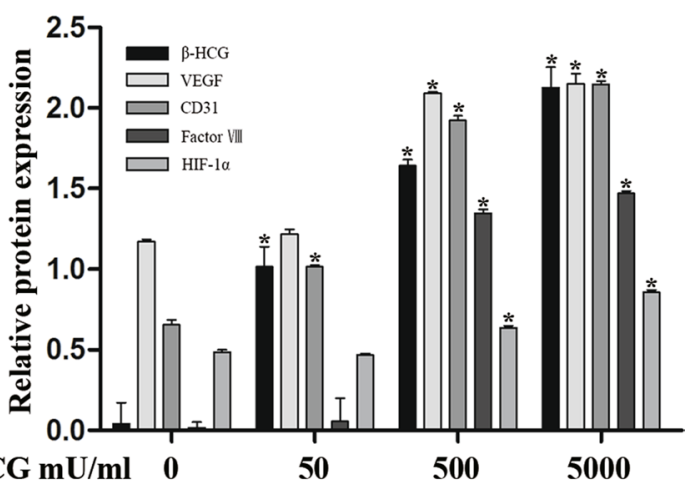

e
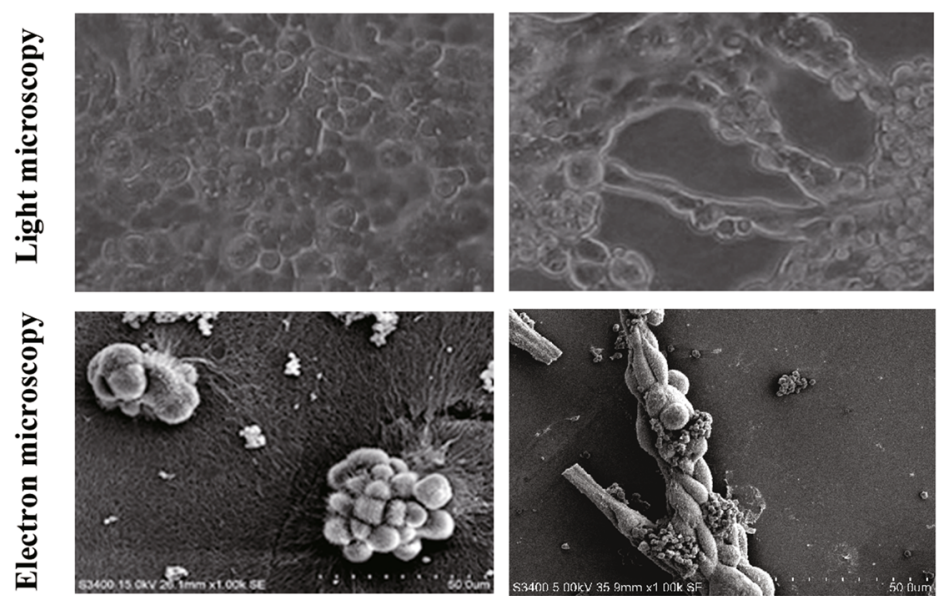

Untreated cells
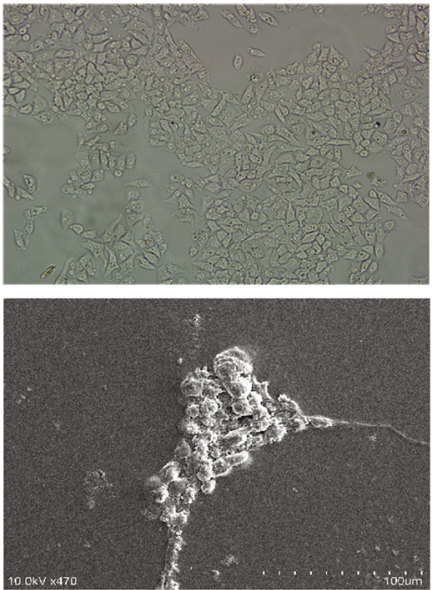

HCG treatment

SKOV3 
(See figure on previous page.)

Fig. 1 Expression of vascular cell markers and hCG in and morphological flexibility of hCG-treated OVCAR-3 cells. a, b Expression levels of vascular markers CD31, VEGF, factor VIII, hCG, and HIF-1 a were determined in OVCAR-3 cells exposed to 50, 500, or $5000 \mathrm{mU} / \mathrm{ml} \mathrm{hCG} \mathrm{for} 7$ days. HCG treatment stimulated the expression of vascular markers and HIF-1 $a$ in OVCAR-3 cells in a dose-dependent manner. a The mRNA levels were analysed by RT-PCR. b Protein levels were detected by western blotting. $\mathbf{c}, \mathbf{d}$ Band densities were quantified by densitometric analysis. Protein and mRNA content was quantified for 3 independent replicates and the data are presented as the mean \pm SD. The data shown are presented after normalization with GAPDH expression and were analysed using 1-way ANOVA. ${ }^{*} \mathrm{p}<0.01,{ }^{*} \mathrm{p}<0.05$. e Light and scanning-electron microscopy observations showed tubular network and channel formation by OVCAR-3 cells in the 3D matrix after exposure to $5000 \mathrm{mU} / \mathrm{ml}$ hCG. Representative morphological changes are shown
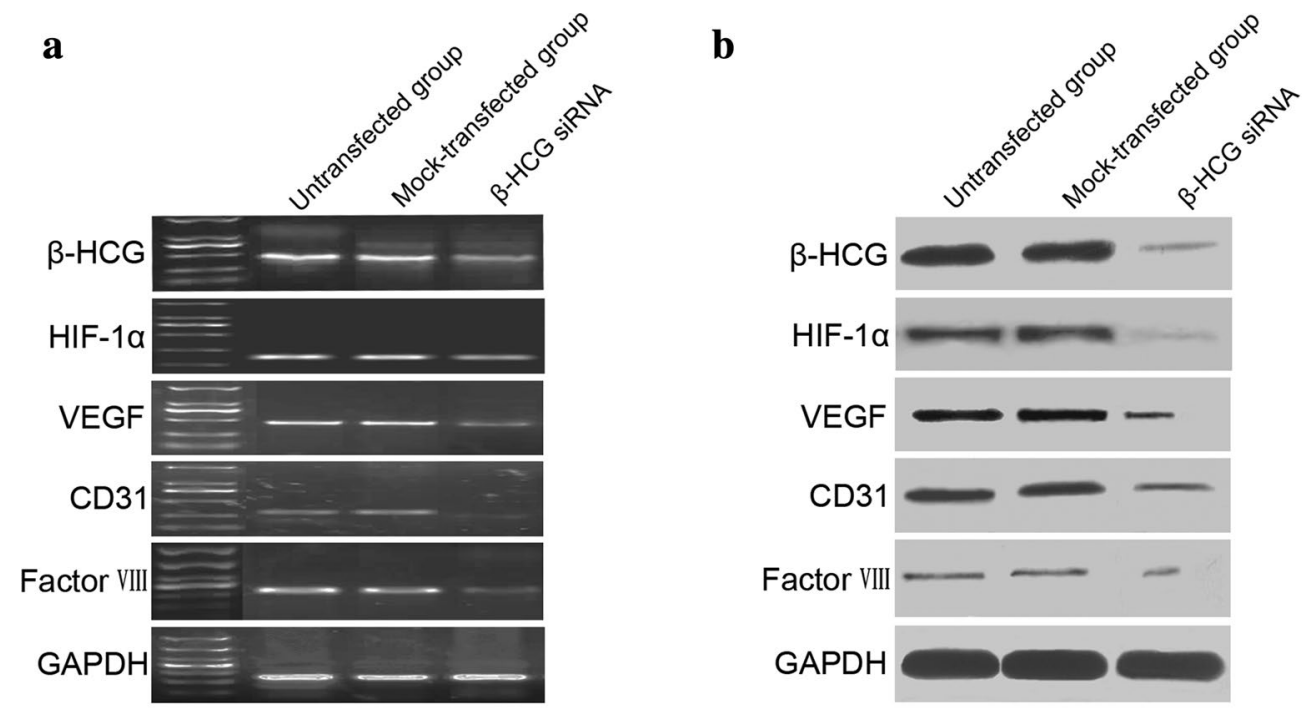

c

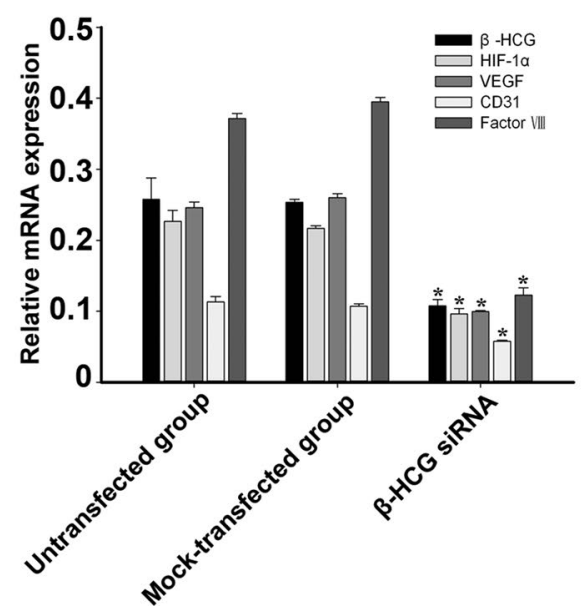

d

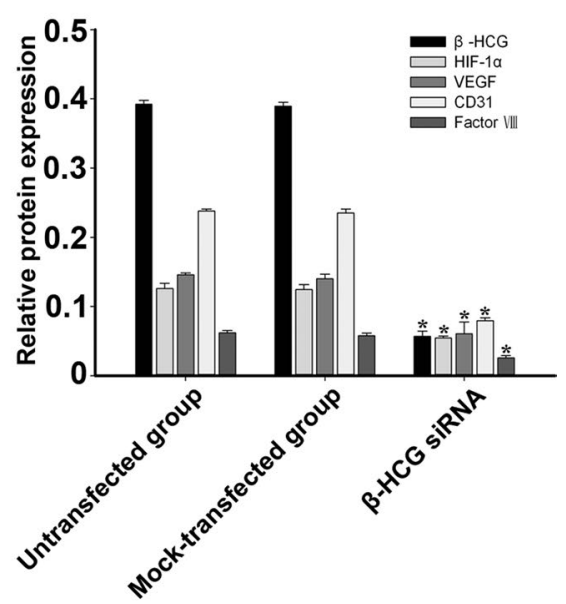

Fig. 2 Inhibition of hCG expression using siRNA resulted in suppressed vascular marker and HIF-1a expression. $\mathbf{a}$, b Expression of hCG in OVCAR-3 cells was inhibited by siRNA targeting hCG mRNA, but not by a negative control siRNA. Compared with untransfected OVCAR-3 cells and mocktransfected OVCAR-3 cells, the expression of CD31, VEGF, factor VIII, and HIF-1 a decreased in OVCAR-3 cells transfected with hCG siRNA. a mRNA expression of the vascular cell marker, HIF-1a and hCG was analysed by RT-PCR. b Protein expression of the vascular cell marker, HIF-1a and hCG was analysed by western blotting. $\mathbf{c}, \mathbf{d}$ Band densities were quantified by densitometric analysis. Protein and mRNA content measured in 3 independent replicates was quantified and the data are presented as the mean \pm SD. The data shown are presented after normalization with GAPDH bands and analysed by 1-way ANOVA. * $p<0.01$ 

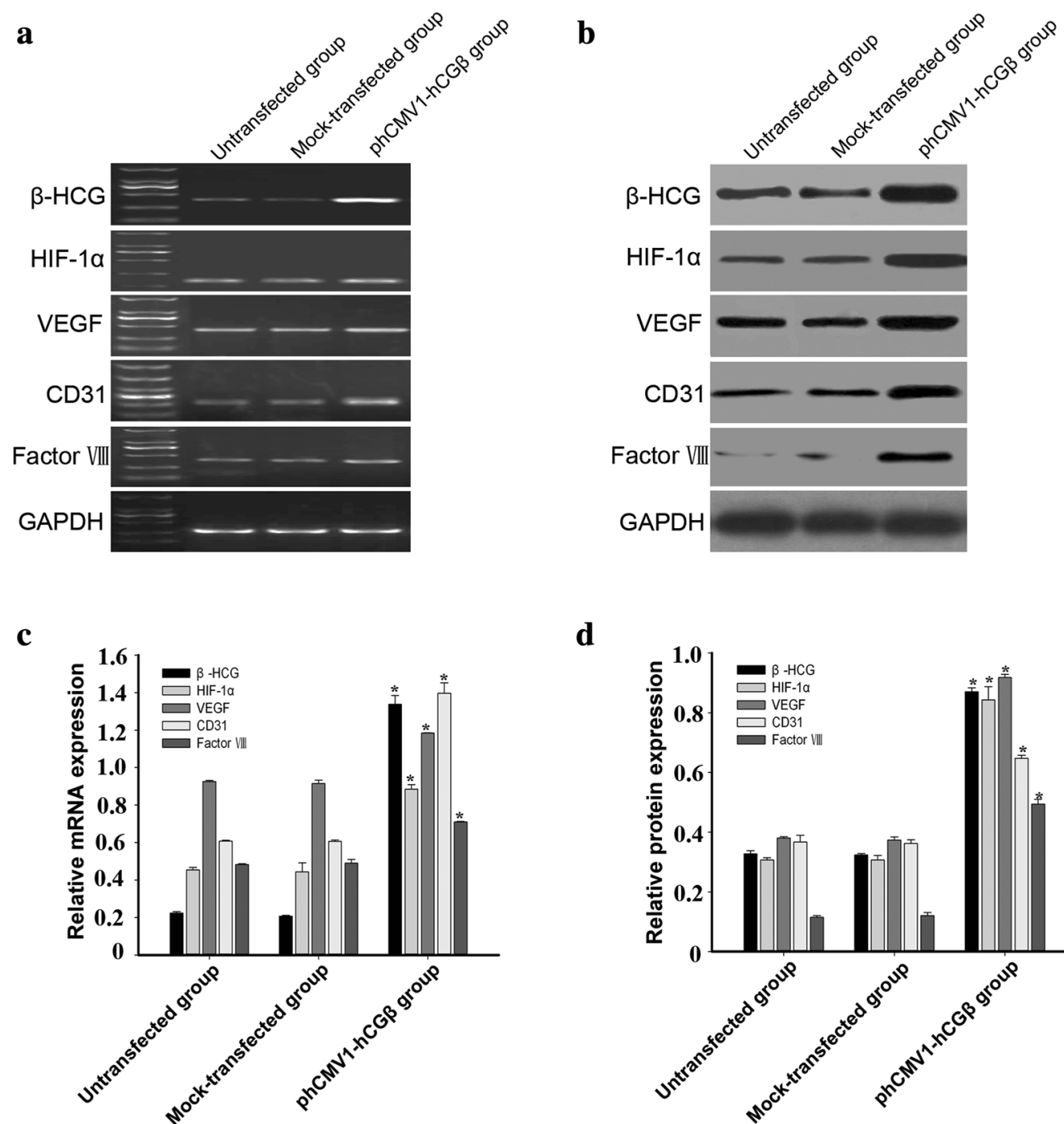

d

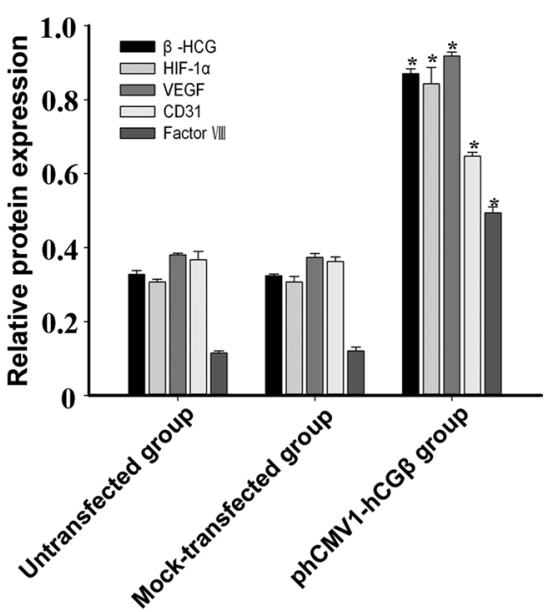

Fig. 3 Up-regulated expression of vascular markers and HIF-1a in OVCAR-3 cells transfected with the phCMV1 vector expressing $\beta$-hCG (phCMV1hCG $)$. a, b HCG expression increased significantly in transfected OVCAR-3 cells, as determined by RT-PCR and western blot analysis. Compared with untransfected and mock-transfected cells, both mRNA (a) and protein expression (b) of CD31, VEGF, Factor VIII, and HIF-1a increased significantly. $\mathbf{c}$, d Band densities were quantified by densitometric analysis. Protein and mRNA content measured in 3 independent replicates was quantified and the data are presented as the mean \pm SD. The data shown were normalized to GAPDH bands and analysed by 1-way ANOVA. ${ }^{*} p<0.01$

levels of CD31, VEGF, and factor VIII, compared with untransfected and mock-transfected cells. Overexpression of hCG also resulted in a twofold enhancement of HIF-1 $\alpha$ expression (Fig. 3).

\section{Expression of the hCG receptor (hCG-R) in OVCAR-3 cells}

We confirmed that the hCG receptor was expressed in OVCAR-3 cells by confocal microscopy. The green fluorescence was localized to the periphery of OVCAR-3 cells (Fig. 4a). Expression of the hCG receptor in OVCAR-3 cells exposed to 50, 500, or $5000 \mathrm{mU} / \mathrm{ml} \mathrm{hCG}$ for 7 days were analysed by RT-PCR and western blotting. As shown in Fig. $4 \mathrm{~b}-\mathrm{e}$, treatment of OVCAR-3 cells with different hCG concentrations did not significantly affect expression of the hCG receptor.

\section{Discussion}

$\mathrm{VM}$ is the ability of aggressive cancer cells to acquire an altered phenotype and form a tumour cell-lined vasculature. The tumour cells can express endothelium-associated markers during VM. In tumour vessel channels non-endothelial cells have been found to express typical endothelial markers as seen in uveal melanoma cells which express the endothelial cell markers CD31 and CD34 [23]. 
$\mathbf{a}$

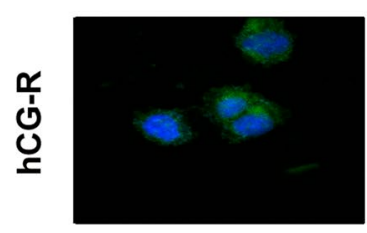

b

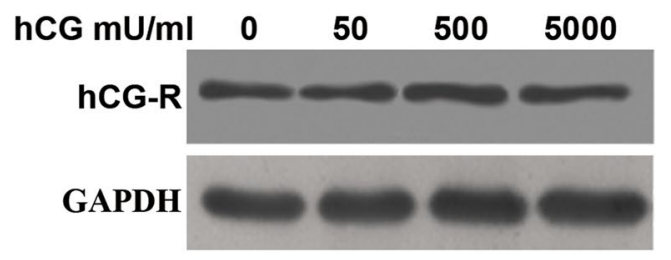

d

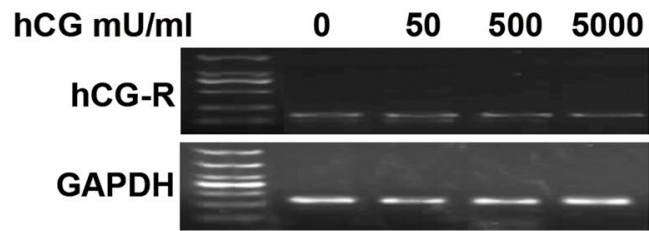

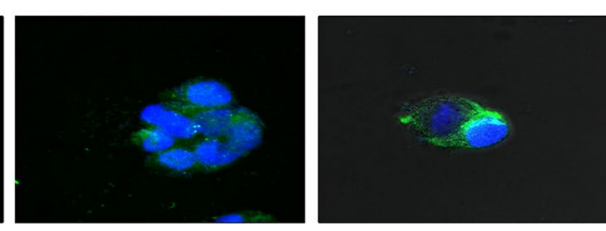

c

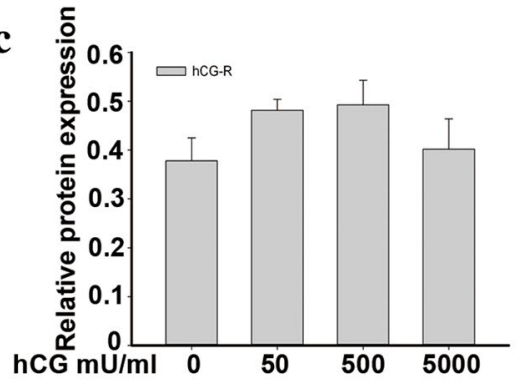

e

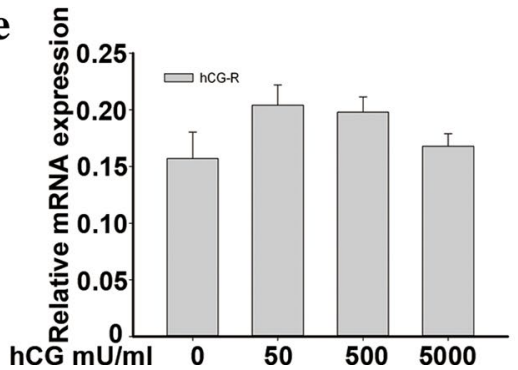

Fig. 4 Expression of the hCG receptor (hCG-R) in the ovarian cancer cell line OVACR-3. a Confocal image of OVCAR-3 cells following immunofluorescence staining with an hCG-R antibody. Green fluorescence was localized to the periphery of OVCAR-3 cells. Blue fluorescence (PI) was used to demonstrate the nucleus. $\mathbf{b}$, d Different concentrations of hCG did not significantly affect hCG-R expression in OVCAR-3 cells. b Protein expression of hCG-R in OVCAR-3 cells treated with $\mathrm{hCG}(0,50,500$, or $5000 \mathrm{mU} / \mathrm{ml})$ for 7 days was detected by western blot analysis. $\mathbf{d}$ Expression of $\mathrm{hCG}$ - $\mathrm{R}$ mRNA in OVCAR-3 treated with hCG $(50,500$, or $5000 \mathrm{mU} / \mathrm{ml})$ was detected by RT-PCR. c, e Band densities were quantified by densitometric analysis. The protein and mRNA content measured in 3 independent replicates was quantified and the data are presented as the mean \pm SD. The data shown were normalized to GAPDH bands and analysed using 1-way ANOVA. $p>0.05$

Human glioma stem/progenitor cells can transdifferentiate into vascular endothelial cells (VECs) and express VECs markers including CD31, CD34, and vWF significantly under hypoxia [24]. Von Willebrand factor (VWF), a glycoprotein mainly secreted from endothelial cells, is a carrier protein of coagulation factor VIII (FVIII). Factor VIII-associated antigen are vasculogenic mimicry markers [25]. VEGF is a major angiogenesis regulator of human endothelial cells. VEGF appears to contribute to VM formation in some cancer types including ovarian carcinoma [26]. In our study, VM was identified by morphological observations and detection of vascular endothelial cell markers CD31, VEGF, Factor VIII in ovarian cancer cells.

It has been reported that ovarian cancer SKOV3 cells could differentiate into endothelial-like cells and form channels on scaffolds in a microenvironment with low oxygen tension [2]. Our previous findings showed that a microenvironment with hCG localized to scaffolds strongly induced VM in hCG receptor-positive ovarian cancer OVCAR-3 cells, even under normoxic conditions [12].
HCG is a heterodimeric hormone that is primarily produced by the placenta, but is also produced by other normal and cancer tissues at low levels [27, 28]. The human epithelial ovarian cancer cell line OVCAR-3 not only synthesizes hCG, but also expresses hCG receptor on the cell membrane. HCG serves a role in angiogenesis both in vivo and in vitro by increasing capillary formation and endothelial cell migration [29-31]. Berndt et al. [32] demonstrated a direct angiogenic effect of hCG between blastocysts and the maternal endometrium in several experimental models. HCG can also facilitate trophoblast differentiation [33] and positively influence angiogenesis by inducing VEGF and matrix metalloproteinase 9 expression [34]. The angiogenic function of tumourderived hCG in VM has not been reported.

The angiogenic activity of hCG was investigated here by detecting expression differences in the vascular marker and morphological alterations in OVCAR-3 cells in 3D gels. The addition of exogenous hCG induced expression of vascular markers in OVCAR-3 in a dose-dependent manner, with a dose of $5000 \mathrm{mU} / \mathrm{ml}$ hCG in 3D gels 
showing the strongest influence on vessel-like tube formation by OVCAR-3 cells. These results indicated that hCG potentially affects VM.

In an effort to better understand the involvement of hCG in mediating VM in ovarian cancer cells, siRNA was used to block hCG expression and study its effect on the expression of vascular markers in OVCAR-3 cells. Transfection of the antisense hCG gene resulted in a significant inhibition of vascular cell marker expression in OVCAR-3 cells. OVCAR-3 cells were also transfected with the phCMV1 vector, which drove hCG overexpression and significantly increased vascular cell marker expression. Our data indicated that hCG promotes the trans-differentiation of OVCAR-3 cells into endothelial-like cells.

However, in hCG receptor-negative SKOV3 cells, exogenous hCG failed to induce VM formation. These data suggested that the hormone may act specifically through the hCG receptor. The activity of hCG is initiated by binding of hCG to its transmembrane glycoprotein receptor, which is a member of the $G$ protein-coupled receptor superfamily [35]. Adenylate cyclase on the internal membrane is then stimulated to convert adenosine triphosphate into cyclic adenosine monophosphate [36]. Immunofluorescence staining, RT-PCR, and western blot data detected stable expression of the hCG receptor in the OVCAR-3 cell line. Although OVCAR-3 cells are positive for the hCG receptor, treatment of OVCAR-3 with increasing doses of exogenous hCG had no significant effect on expression of the hCG receptor, suggesting other possible regulatory pathways involved in the effect of hCG [37], which should be a subject of future studies.

We also investigated the effect of hCG on HIF- $1 \alpha$ expression. Expression of HIF-1 $\alpha$ in OVCAR-3 cells was up-regulated following hCG treatment or transfection with the phCMV1 vector, which drove overexpression of hCG. Conversely, attenuating hCG expression in OVCAR-3 cells via siRNA suppressed HIF- $1 \alpha$ expression. HIF- $1 \alpha$ is a key transcription factor that mediates responses to oxygen deprivation [38]. Hypoxia, an important feature of the tumour microenvironment, is known to mediate tumour VM through HIF-1 $\alpha$ [2, 4]. Driesche et al. [39] demonstrated that HIF-1 $\alpha$ expression was induced by hCG in luteinizing granulosa cells under both hypoxic and normoxic conditions. Our present data indicated that hCG is an important regulator of HIF-1 $\alpha$ and its downstream target, the vascular marker VEGF [40, 41]. We propose that hCG may exert its angiogenic effect through the HIF-1 $\alpha$-VEGF pathway.

\section{Conclusions}

These results may offer new insights into the possible regulatory role of hCG in VM formation in ovarian cancer. The hCG receptor in OVCAR-3 ovarian cancer cells may potentially serve as a novel target in cancer therapy. Further studies are required to evaluate the signal transduction pathways involved in the activity of hCG in VM of ovarian cancer.

\section{Methods \\ HCG treatment in 3D cultures}

The human epithelial ovarian cancer cell lines OVCAR-3 and SKOV3 were purchased from the American Type Culture Collection (Manassas, VA). One hundred and fifty microliters of a co-mixture of Matrigel (BectonDickinson, Bedford, MA) and McCoy-5A/RPMI1640 (Gibco, Invitrogen, Carlsbad, CA) was dropped onto glass coverslips in 24-well culture plates and allowed to incubate for $30 \mathrm{~min}$ at $37{ }^{\circ} \mathrm{C}$ in a humidified $5 \% \mathrm{CO}_{2}$ incubator. The medium contained $15 \%$ foetal calf serum and was changed every $48 \mathrm{~h}$. Tumour cells $\left(1 \times 10^{5}\right)$ were seeded onto the gels. Tumour cells were then exposed to different concentrations of recombinant hCG $(50,500$, or $5000 \mathrm{mU} / \mathrm{ml}$ ) for 7 days. HCG was obtained from Sigma (St Louis, MO, USA).

\section{RT-PCR experiments}

Total RNA was isolated from the cultured OVCAR-3 cells using the TRIZOL reagent (Invitrogen, San Diego, CA). First-strand cDNA was synthesized from $2 \mu \mathrm{g}$ total RNA using oligo-dT primer $\left(\mathrm{T}_{18}\right)$ and reverse transcriptase (Promega, Southampton, UK). Amplification of cDNA was performed in a PerkinElmer Thermal Cycler (GeneAmp PCR Instruments Systems, Roche, Branchburg, NJ). We devised primers with the following sequences: $\beta$-hCG: $5^{\prime}$-ACATGGGCATCCAAGGAGC-3' ${ }^{\prime}$, ${ }^{\prime}$-GGATTGAGA AGCCTTTATTGTGG-3' (461 bp); hCG receptor: 5'-TCTATGCCCTATCTGGATTCTAC-3' and $5^{\prime}$-GGTT CCTACTCACGAGGAGTTTA-3' (156 bp); CD31: $5^{\prime}$-AC CAAGATAGCCTCAAAGTCG- ${ }^{\prime}$ ' and $5^{\prime}$-CCTTCACCC TCAGAACCTCAC-3' (370 bp); VEGF: $5^{\prime}$-TCTGGGCTG TTCTCGCTTCGG- $3^{\prime}$ and $5^{\prime}$-AGCAGCAAGGCAAGG CTCCAAT-3' (414 bp); factor-VIII: 5'-CCCACCGTTAC TGACTCGCTAC- $3^{\prime}$ and $5^{\prime}$-ATGCTTTCATGCAGGTT TCTCC-3' (392 bp); HIF-1 $\alpha$ : 5'-AAGTGTACCCTAACT AGCCG-3' and 5'-TCACAAATCAGCACCAAGC-3' (161 bp); and GAPDH: 5'-CCATTTGCAGTGGCAAA G-3 and 5'-CACCCCATTTGATGTTAGTG-3' (202 bp). PCR amplification was performed using the following thermocycling conditions: $95{ }^{\circ} \mathrm{C}$ for $5 \mathrm{~min}$, followed by 40 cycles of denaturation at $94{ }^{\circ} \mathrm{C}$ for $1 \mathrm{~min}$, annealing at $56{ }^{\circ} \mathrm{C}$ for $45 \mathrm{~s}$ (hCG), $58{ }^{\circ} \mathrm{C}$ for $1 \mathrm{~min}$ (hCG-R), $50{ }^{\circ} \mathrm{C}$ for $45 \mathrm{~s}$ (CD31), $60{ }^{\circ} \mathrm{C}$ for $45 \mathrm{~s}$ (VEGF), $60{ }^{\circ} \mathrm{C}$ for $45 \mathrm{~s}$ (factor VIII), or $60^{\circ} \mathrm{C}$ for $30 \mathrm{~s}$ (HIF-1 $\alpha$ ); and then a final extension step at $72{ }^{\circ} \mathrm{C}$ for $10 \mathrm{~min}$. All amplified products were separated in $1 \%$ agarose gels, and the bands 
were visualized by ethidium bromide staining. In order to semi-quantify the expression level of mRNA, the gels were scanned with standard imaging equipment and the images were analysed with an image analysis software. mRNA contents in the three independent replicates were respectively quantified and presented as mean $\pm S D$.

\section{Western blot analysis}

Mouse monoclonal antibodies against VEGF, factor VIII, $\beta$-hCG, hCG receptor, and HIF- $1 \alpha$ were obtained from Santa Cruz Biotechnology (Santa Cruz, CA, USA). A rabbit monoclonal antibody against CD31 was obtained from Bioworld (Dublin, OH). Cellular proteins were isolated after rinsing cells with ice-cold phosphatebuffered saline (PBS; pH 7.4) and lysing them on ice with a protein-extraction reagent. The proteins were then separated on an $8 \%$ sodium dodecyl sulphideTris polyacrylamide gel. Transfer to a polyvinylidene fluoride membrane was performed at $0.27 \mathrm{~mA}$ for $2 \mathrm{~h}$. The membranes were blocked overnight with $1 \times$ Trisbuffered saline containing $0.1 \%$ Tween 20 and $5 \%$ skim milk, followed by incubation with primary antibody (1:100) for $1 \mathrm{~h}$ and a horseradish peroxidase-conjugated secondary antibody (1:1000) for an additional $1 \mathrm{~h}$ at room temperature. Immunocomplexes were visualized by electrochemiluminescence. Protein expression was semi-quantified using a Tiannen imager and analysis system (Shanghai, China). Protein contents in the three independent replicates were respectively quantified and presented as mean $\pm \mathrm{SD}$.

\section{Immunofluorescence staining and confocal microscopy observations}

After fixing slides with paraformaldehyde, they were rinsed twice in PBST for $5 \mathrm{~min}$. The slides were then immersed in $3 \%$ hydrogen peroxide for $20 \mathrm{~min}$ to quench endogenous peroxidase activity. The specimens were pre-blocked for $30 \mathrm{~min}$ in bovine albumin serum. Subsequently, the slides were incubated with a rabbit polyclonal antibody against the hCG receptor (Santa Cruz, CA, USA) at a 1:100 dilution for $1 \mathrm{~h}$ at room temperature. After washing 3 times in PBS, the slides were incubated with a fluorescein isothiocyanate-conjugated anti-rabbit immunoglobulin (Santa Cruz, CA, USA) at a 1:100 dilution for $1 \mathrm{~h}$ at room temperature. Negative controls were prepared by replacing the primary antibody with Trisbuffered saline. Samples known to be positive for the hCG receptor served as positive controls. A Leica DM IRE2 confocal laser scanning system (oil immersion objectives $\left.63^{\prime}\right)$ with a helium ion/green neon laser $(543 \mathrm{~nm}$ ) was used. Images were collected and processed using Leica confocal software 2.0 and Adobe Photoshop 6.0.

\section{Small interference RNA (siRNA)}

HCG siRNAs were synthesized and ligated into the PGPU6/GFP/Neo vector by Jima Biologic Technology Co. (Shanghai, China). The sequence of pSilencer/ $\beta$ hCG was 5'-CCCGAGGTATAAAGCCAGGTACA-3'. OVCAR-3 cells were seeded in 6-well plates and grown to 70-90\% confluency in the absence of antibiotics. Transfections were performed with $0.8 \mu \mathrm{g}$ of the silencing plasmid PGPU6/GFP/Neo- $\beta$-hCG and $2 \mu$ l Lipofectamine ${ }^{\text {TM }}$ 2000 (Invitrogen, Carlsbad, CA, USA), following the manufacturer's recommended protocol. Control cells were mock-transfected. At $24 \mathrm{~h}$ post-transfection, the transfection efficiency was assessed by fluorescence microscopy, revealed that $80 \%$ of the transfectants were positive for green fluorescent protein expression. Stably transfected cells were selected in G418 $(0.4 \mathrm{mg} / \mathrm{ml}$; Merck, Darmstadt, Germany) for approximately 2 weeks. The efficiency of $\beta$-hCG silencing was analysed by RTPCR and western blotting.

\section{Construction of the phCMV1 vector expressing $\beta$-hCG (phCMV1-hCG $\beta$ )}

The recombinant phCMV1-hCG $\beta$ plasmid was constructed based on the phCMV1 vector (Gene Therapy System), which encodes the cytomegalovirus mediatedearly promoter plus intron A, followed by the SV40 polyA expression cassette. The vector expressing hCG was generated by cloning the sequences encoding hCG into the phCMV1 vector, using unique restriction endonuclease sites. PCR amplification of hCG was performed using the sense primer $5^{\prime}$-CGGAATTCTCC AAGGAGCCGCTTCGG-3' ${ }^{\prime}$ and the antisense primer 5'-CGGGATCCTTGTGGGAGGATCGG-3'. OVCAR-3 cells were transfected with $2 \mu \mathrm{g}$ of DNA using $6 \mu \mathrm{g}$ Lipofectamine $^{\mathrm{TM}} 2000$ (Invitrogen, Carlsbad, CA, USA), according to the manufacture's guidelines. The resistant clones were selected in G418 $(800 \mu \mathrm{g} / \mathrm{ml})$ for 7 days and expanded in $300 \mu \mathrm{g} / \mathrm{ml} \mathrm{G} 418$.

\section{Statistical analysis}

All experiments were performed at least 3 times. The results are presented as the mean \pm standard deviation (SD). The data were analysed using SPSS 16.0 for Windows software (SPSS, Inc., Chicago, IL). One-way analysis of variance (ANOVA) was performed to identify statistical differences.

\section{Abbreviations}

3D: 3-dimensional; ANOVA: analysis of variance; hCG: human chorionic gonadotropin; hCG-R: human chorionic gonadotropin receptor; HIF-1a: hypoxiainducible factor-1a; RT-PCR: reverse transcription-polymerase chain reaction; siRNA: small interfering RNA; VEGF: vascular endothelial growth factor; VM: vasculogenic mimicry. 


\section{Authors' contributions}

MS, XX, and WW performed the experiments. MS, CC, and YZ designed or conceived the experiments. SG, XW and CC contributed reagents, materials, and analysis tools. XX,WW, and MS wrote the manuscript. MS, CC, and YZ edited the manuscript. All authors read and approved the final manuscript.

\section{Author details}

1 Department of Obstetrics and Gynecology, The Affiliated Hospital of Nantong University, No 20, Xisi Rd, Nantong 226001, People's Republic of China. ${ }^{2}$ Present Address: Suzhou Municipal Hospital, Suzhou, China. ${ }^{3}$ Present Address: Changzhou 2nd People's Hospital, Changzhou, China. ${ }^{4}$ The Immunology Laboratory of Nantong University, Nantong, China. ${ }^{5}$ Department of Genetics, College of Life Sciences, Nantong University, Nantong, Jiangsu, China.

\section{Acknowledgements}

We thank Professor Youji Feng and Professor Dajing Li for their excellent academic assistance. This work was supported by a Grant from the National Natural Science Foundation of China (Grant No. 30801226).

\section{Competing interests}

The authors declare that they have no competing interests.

Received: 7 September 2013 Accepted: 8 June 2016

Published online: 24 June 2016

\section{References}

1. Maniotis AJ, Folberg R, Hess A, Seftor EA, Gardner LM, Pe'er J, et al. Vascular channel formation by human melanoma cells in vivo and in vitro: vasculogenic mimicry. Am J Pathol. 1999;155:739-52.

2. Yao LQ, Feng YJ, Ding JX, Jing HM, Xu CJ, Chen SF, et al. Differentiation of vascular endothelial cells-like derived from epithelial ovarian cancer cells induced by hypoxia. Int J Oncol. 2007;30:1069-75.

3. Vartanian AA, Stepanova EV, Gutorov SL, Solomko ES, Grigorieva IN, Sokolova IN, et al. Prognostic significance of periodic acid-Schiff-positive patterns in clear cell renal cell carcinoma. Can J Urol. 2009;16:4726-32.

4. Su M, Yao LQ, Feng YJ, Cheng MJ, Xu CJ, Huang Y, et al. Plasticity of ovarian cancer cell and vasculogenic mimicry in vivo. Int J Gynecol Cancer. 2008;18:476-86.

5. Clemente M, Perez M, Illera J, Pena L. Histological, immunohistological, and ultrastructural description of vasculogenic mimicry in canine mammary cancer. Vet Pathol. 2010;47:265-74.

6. Liu C, Huang HN, Doñate F, Dickinson C, Santucci R, El-Sheikh A, et al. Prostate-specific membrane antigen directed selective thrombotic infarction of tumors. Cancer Res. 2002;62:5470-5.

7. Scavelli C, Nico B, Cirulli T, Ria R, Pietro GD, Mangieri D, et al. Vasculogenic mimicry by bone marrow macrophages in patients with multiple myeloma. Oncogene. 2008;27:663-74.

8. Guzman G, Cotler SJ, Lin AY, Maniotis AJ, Folberg R. A pilot study of vasculogenic mimicry immunohistochemical expression in hepatocellular carcinoma. Arch Pathol Lab Med. 2007:131:1776-81.

9. van der Schaft DW, Hillen F, Pauwels P, Kirschmann DA, Castermans K, Egbrink MG, et al. Tumor cell plasticity in Ewing sarcoma, an alternative circulatory system stimulated by hypoxia. Cancer Res. 2005;65:11520-8.

10. Sun BC, Zhang DF, Zhang SW, Zhang WZ, Guo H, Zhao XL. Hypoxia influences vasculogenic mimicry channel formation and tumor invasionrelated protein expression in melanoma. Cancer Lett. 2007:249:188-97.

11. Corzo CA, Condamine T, Lu L, Cotter MJ, Youn JI, Cheng PY, et al. HIF-1 a regulates function and differentiation of myeloid-derived suppressor cells in the tumor microenvironment. J Exp Med. 2010;207:2439-53.

12. Su M, Wei W, Xu X, Wang X, Chen C, Su L, Zhang Y. The role of hCG in vasculogenic mimicry in OVCAR-3 ovarian cancer cell line. Int J Gynecol Cancer. 2011;21:1366-74.

13. Su M, Fan C, Gao SN, Shen AG, Wang XY, Zhang YQ. An HCG-rich microenvironment contributes to ovarian cancer cell differentiation into endothelioid cells in a three-dimensional culture system. Oncol Rep. 2015;34:2395-402.
14. Hussa RO. Biosynthesis of human chorionic gonadotropin. Endocr Rev. 1980;1:268-94

15. Lempiäinen A, Stenman UH, Blomqvist C, Hotakainen K. Free $\beta$-subunit of human chorionic gonadotropin in serum is a diagnostically sensitive marker of seminomatous testicular cancer. Clin Chem. 2008:54:1840-3.

16. Iles RK, Delves PJ, Butler SA. Does hCG or hCG $\beta$ play a role in cancer cell biology? Mol Cell Endocrinol. 2010;329:62-70.

17. Vartiainen J, Lassus H, Lehtovirta P, Finne P, Alfthan H, Butzow R, et al. Combination of serum hCG beta and p53 tissue expression defines distinct subgroups of serous ovarian carcinoma. Int J Cancer. 2008;122:2125-9.

18. Iles RK. Ectopic hCG $\beta$ expression by epithelial cancer: malignant behavior metastasis and inhibition of tumor cell apoptosis. Mol Cell Endocrinol. 2007;260:264-70.

19. Sun BC, Zhang SW, Zhao X, Zhang W, Hao X. Vasculogenic mimicry is associated with poor survival in patients with mesothelial sarcomas and alveolar rhabdomyosarcomas. Int J Oncol. 2004;25:1609-14.

20. Herr F, Baal N, Reisinger K, Lorenz A, McKinnon T, Preissner KT, et al. hCG in the regulation of placental angiogenesis. Results of an in vitro study. Placenta. 2007:28:585-93

21. Li D, Wen X, Ghali L, Al-Shalabi FM, Docherty SM, Purkis P, et al. hCG beta expression by cervical squamous carcinoma-in vivo histological association with tumour invasion and apoptosis. Histopathology. 2008;53:147-55.

22. Arrieta O, Michel Ortega RM, Angeles-Sánchez J, Villarreal-Garza C, AvilesSalas A, Chanona-Vilchis JG, et al. Serum human chorionic gonadotropin is associated with angiogenesis in germ cell testicular tumors. J Exp Clin Cancer Res. 2009;28:120.

23. Folberg R, Maniotis AJ. Vasculogenic mimicry. Acta Pathol. 2004:112:508.

24. Dong J, Zhao YD, Huang Q, Fei XF, Diao Y, Shen YT, Xiao H, Zhang TY, Lan Q, Gu XS. Glioma stem/progenitor cells contribute to neovascularization via transdifferentiation. Stem Cell Rev Rep. 2011;7:141-52.

25. Petty AP, Garman KL, Winn VD, Spidel CM, Lindsey JS. Overexpression of carcinoma and embryonic cytotrophoblast cell-specific Mig-7 induces invasion and vessel-like structure formation. Am J Pathol. 2007:170:1763-80

26. Wang JY, Sun T, Zhao XL, Zhang SW, Zhang DF, Gu Q, Wang XH, Zhao $\mathrm{N}$, Qie S, Sun BC. Functional significance of VEGF-a in human ovarian carcinoma: role in vasculogenic mimicry. Cancer Biol Ther. 2008;7:758-66.

27. Daniel KD, Kim GY, Vassiliou CC, Jalali-Yazdi F, Langer R, Cima MJ. Multireservoir device for detecting a soluble cancer biomarker. Lab Chip. 2007:7:1288-93.

28. Jankowska AG, Andrusiewicz M, Fischer N, Warchol PJ. Expression of hCG and $\mathrm{GnRHs}$ and their receptors in endometrial carcinoma and hyperplasia. Int J Gynecol Cancer. 2010;20:92-101.

29. Michel RM, Aguilar JL, Arrieta O. Human chorionic gonadotropin as an angiogenic factor in breast cancer during pregnancy. Med Hypotheses. 2007;68:1035-40.

30. Phan B, Rakenius A, Pietrowski D, Bettendorf H, Keck C, Herr D. hCGdependent regulation of angiogenic factors in human granulosa lutein cells. Mol Reprod Dev. 2006:73:878-84.

31. Pietrowski D, Wiehle P, Sator M, Just A, Keck C. Regulation of the angiopoietin-2 gene by hCG in ovarian cancer cell line OVCAR-3. Horm Metab Res. 2010;42:328-33.

32. Berndt S, Perrier HS, Blacher S, Péqueux C, Lorquet S, Munaut C, et al. Angiogenic activity of human chorionic gonadotropin through $\mathrm{LH}$ receptor activation on endothelial and epithelial cells of the endometrium. FASEB J. 2006;20:2630-2.

33. Kliman HJ, Nestler JE, Sermasi E, Sanger JM, Strauss JF 3rd. Purification, characterization, and in vitro differentiation of cytotrophoblasts from human term placentae. Endocrinology. 1986;1 18:1567-82.

34. Licht $P$, Fluhr $H$, Neuwinger J, Wallwiener D, Wildt L. Is human chorionic gonadotropin directly involved in the regulation of human implantation? Mol Cell Endocrinol. 2007:269:85-92.

35. Jiang XS, Russo IH, Russo J. Alternately spliced luteinizing hormone/ human chorionic gonadotropin receptor mRNA in human breast epithelial cells. Int J Oncol. 2002;20:735-8.

36. Dabizzi S, Noci I, Borri P, Borrani E, Giachi M, Balzi M, et al. Luteinizing hormone increases human endometrial cancer cells invasiveness through activation of protein kinase A. Cancer Res. 2003;63:4281-6. 
37. Srisuparp S, Strakova Z, Brudney A, Mukherjee S, Reierstad S, HunzickerDunn $M$, et al. Signal transduction pathways activated by chorionic gonadotropin in the primate endometrial epithelial cells. Biol Reprod. 2003;68:457-64.

38. Savai R, Schermuly RT, Voswinckel R, Renigunta A, Reichmann B, Eul B, et al. HIF-1 a attenuates tumor growth in spite of augmented vascularization in an A549 adenocarcinoma mouse model. Int J Oncol. 2005;27:393-400.

39. van den Driesche S, Myers M, Gay E, Thong KJ, Duncanet WC. hCG upregulates hypoxia inducible factor-1 alpha in luteinized granulosa cells: implications for the hormonal regulation of vascular endothelial growth factor $A$ in the human corpus luteum. Mol Hum Reprod. 2008;14:455-64.
40. Dong $X$, Wang YS, Dou GR, Hou HY, Shi YY, Zhang R, et al. Influence of Dll4 via HIF-1a-VEGF signaling on the angiogenesis of choroidal neovascularization under hypoxic conditions. PLoS One. 2011;6:18481.

41. Simiantonaki N, Jayasinghe C, Michel-Schmidt R, Peters K, Hermanns MI, Kirkpatrick CJ. Hypoxia-induced epithelial VEGF-CNEGFR-3 upregulation in carcinoma cell lines. Int J Oncol. 2008;32:585-92.

\section{Submit your next manuscript to BioMed Central and we will help you at every step:}

- We accept pre-submission inquiries

- Our selector tool helps you to find the most relevant journal

- We provide round the clock customer support

- Convenient online submission

- Thorough peer review

- Inclusion in PubMed and all major indexing services

- Maximum visibility for your research

Submit your manuscript at www.biomedcentral com/submit 